\title{
Isolation and characterization of microsatellite loci for the mud-dauber wasp Trypoxylon (Trypargilum) albitarse (Hymenoptera: Crabronidae)
}

\author{
Juliano DA COSTA ALMEIDA ${ }^{1}$, Antonio Carlos BRAGATO BERGAMASCHI ${ }^{1}$, Alexandra SANCHES ${ }^{2}$, \\ TERUmi HATANAKA ${ }^{1}$ and MARco Antonio DEL LAMA ${ }^{1}$ \\ ${ }^{1}$ Departamento de Genética e Evolução, Universidade Federal de São Carlos, 13565-905, São Carlos, SP, Brazil; \\ e-mails: juliano03@gmail.com; caito_bio@yahoo.com.br; hterumi@yahoo.com.br; dmdl@ufscar.br \\ ${ }^{2}$ Departamento de Ecologia, Universidade Estadual Paulista, 13506-900, Rio Claro, SP, Brazil; e-mail: lelesanches@gmail.com
}

Key words. Hymenoptera, Crabronidae, Trypoxylon albitarse, microsatellites, genetic characterization

\begin{abstract}
This paper describes the characterization of a set of nine microsatellite markers for the pipe-organ mud-dauber wasp, Trypoxylon albitarse F. (Hymenoptera: Crabronidae), a common solitary wasp species in Brazil. Eight of the nine loci described were found to be polymorphic. The number of alleles ranged from three to 11. Observed and expected heterozygosity on the population level ranged from 0.135 to 0.891 and 0.177 to 0.865 , respectively. Genotypic analyses revealed no deviations from Hardy-Weinberg equilibrium or linkage disequilibrium after sequential Bonferroni correction. Cross-species amplification was also tested for nine related species and positive amplifications were found in most of the assays. These markers will be useful in studies involving relatedness analysis and investigations of the population genetics of these wasps.
\end{abstract}

\section{INTRODUCTION}

Trypoxylon (Hymenoptera: Crabronidae) is a diverse genus of solitary wasps. Species of the subgenus Trypargilum appear to have several distinctive features, such as nest architecture, cocoon morphology and prey preference (Coville, 1982). Some species construct mud nests, while others utilize pre-existing cavities that are divided into a linear series of cells by mud partitions. The female is responsible for nesting activities and supplies brood cells with paralyzed spiders. A single egg is laid on the abdomen of one of the last spiders stored. A mud partition is placed to seal each cell. Once the nest is completed, the female seals the tube entrance with a thicker plug of mud (Coville, 1982; Brockmann, 1992).

Trypargilum males exhibit guarding behavior during the time the nest is being provisioned by the female (Coville \& Coville, 1980; Brockmann, 1992). Highly polymorphic molecular (DNA) markers, such as microsatellites, are useful tools in attempting to determine the association between guarding behaviour and paternity of the brood (Queller et al., 1993; Hughes, 1998). In the family Crabronidae, such markers have only been developed for the European beewolf, Philanthus triangulum (F.) (subfamily Philanthinae) (Kaltenpoth et al., 2004) and the thin-waisted social wasp, Microstigmus nigrophthalmus Melo (subfamily Pemphredoninae) (Lucas et al., 2009). For our own purposes, it was therefore necessary to develop specific markers for Trypoxylon, which might also prove useful in familial and population genetics studies and provide valuable insights regarding the mating system of these wasps. The aim of the present study was thus to characterize microsatellite loci for the pipe-organ mud-dauber wasp, T. albitarse F., a common solitary wasp species in Brazil, the nests of which are often found in the walls of man-made constructions. Additionally, these loci were tested across nine other wasp species to test for cross amplification of the markers.

\section{MATERIAL AND METHODS}

An enriched partial genomic DNA library was developed essentially as described by Hamilton et al. (1999). DNA was extracted using the phenol-chloroform protocol according to Fernandes-Salomão et al. (2005). DNA extracted from a single individual was digested with restriction enzymes RsaI, BstuI and XmnI (GE Healthcare, Buckinghamshire, UK). After agarose gel electrophoresis, fragments between 400 and $1000 \mathrm{bp}$ were purified from the gel (Wizard SV Gel and PCR Clean-Up System kit, Promega). For enrichment, fragments were hybridized with a mix of eight biotinylated oligonucleotides $\left[(\mathrm{AAAC})_{6},(\mathrm{AAAG})_{6},(\mathrm{AATC})_{6},(\mathrm{AATG})_{6},(\mathrm{ACCT})_{6},(\mathrm{ACAG})_{6}\right.$, $\left.\left.(\mathrm{ACTC})_{6},(\mathrm{ACTG})_{6}\right)\right]$, where after the hybridized fragments were recovered on streptavidin-coated magnetic beads (Streptavidin Magnesphere Paramagnetic Particles, Promega, Madison, USA). Enriched DNA was cloned with DH5-alpha competent cells using the pGEM-T Easy kit (Promega). A total of 144 positive clones were sequenced on a MegaBACE 1000 automated sequencer (GE Healthcare) using the DYEnamic Terminator kit (GE Healthcare).

The CID (Freitas et al., 2008) and Gene Runner 3.05 (Hastings Software Inc., Hastings, NY, USA) programs were used to search for microsatellite sequences and design primers. Polymerase chain reactions (PCRs) were performed using 250 $\mu \mathrm{M}$ of each dNTP, $2.5 \mathrm{mM} \mathrm{MgCl} 2,1.0 \mu \mathrm{M}$ of each primer, $1 \times$ BioTools buffer and $1 \mathrm{U}$ of Taq DNA polymerase (BioTools, Madrid, Spain) in a final volume of $10 \mathrm{uL}$. Amplification was performed in an Eppendorf Mastercycler thermocycler for 30 cycles with an initial denaturation step at $94^{\circ} \mathrm{C}$, followed by 30 $\mathrm{s}$ at $94^{\circ} \mathrm{C}, 20 \mathrm{~s}$ at the locus-specific annealing temperature (Table 1), one min at $72^{\circ} \mathrm{C}$ (elongation) and with a final extension for $10 \mathrm{~min}$.

\section{RESULTS AND DISCUSSION}

In total, seventeen primer pairs were designed and characterized. Of these, nine showed positive amplification, the forward 
TABLE 1. Characterization of nine microsatellite loci in $T$. albitarse. $\mathrm{F}$ - the forward primer sequences; $\mathrm{R}$ - the reverse primer sequences; $\mathrm{Ta}$ - annealing temperature; $\mathrm{Na}$ - observed number of alleles; Ho - observed heterozygosity; He - expected heterozygosity; HWeq - Hardy-Weinberg Equilibrium.

\begin{tabular}{|c|c|c|c|c|c|c|c|c|c|}
\hline Locus & Primer Sequence (5'-3') & Repeat motif & $\mathrm{Ta}$ & $\begin{array}{l}\text { Range } \\
\text { (bp) }\end{array}$ & $\mathrm{Na}$ & Ho & $\mathrm{He}$ & HWeq & $\begin{array}{c}\text { GenBank } \\
\text { accession no. }\end{array}$ \\
\hline Talb01 & $\begin{array}{l}\text { F: CTAGCCTCAGGCGAATTC } \\
\text { R: GATTCGAGTCTTGGTGCTAA }\end{array}$ & $(\mathrm{TC})_{5} \mathrm{TT}(\mathrm{CT})_{3}$ & 58 & $124-132$ & 3 & 0.135 & 0.177 & 0.031 & JX437159 \\
\hline Talb02 & $\begin{array}{l}\text { F: GTCAGCAAACTGGTCATCC } \\
\text { R: CGTAAACTGGTCACTGGTG }\end{array}$ & $(\mathrm{AG})_{3} \mathrm{AA}(\mathrm{AG})_{7}$ & 58 & $227-249$ & 7 & 0.513 & 0.554 & 0.008 & JX437160 \\
\hline Talb03 & $\begin{array}{l}\text { F: CTCCCAGAGCTGCAGTGT } \\
\text { R: TACGAGACGGAAACAGAATG }\end{array}$ & $(\mathrm{GA})_{5}$ & 58 & $197-207$ & 5 & 0.567 & 0.664 & 0.414 & JX437161 \\
\hline Talb05 & $\begin{array}{l}\text { F: GCAACTGAGAGATCGCTTC } \\
\text { R: GTCTGTCAGCGAATAGTCAAG }\end{array}$ & $(\mathrm{AG})_{4} \mathrm{AA}(\mathrm{AG})_{5}$ & 52 & $161-175$ & 11 & 0.864 & 0.840 & 0.119 & JX437162 \\
\hline Talb06 & $\begin{array}{l}\text { F: GCACCGATATTATTAAGTCTCA } \\
\text { R: TGGAAAGAAGTATACATGTTCG }\end{array}$ & $(\mathrm{AG})_{9}$ & 52 & $268-282$ & 6 & 0.648 & 0.709 & 0.082 & JX437163 \\
\hline Talb07 & $\begin{array}{l}\text { F: TCGCTGCCGACAATTATC } \\
\text { R: GCAGTATTGAATCGGGTAAG }\end{array}$ & $(\mathrm{TC})_{14}$ & 52 & $196-226$ & 10 & 0.891 & 0.865 & 0.332 & JX437164 \\
\hline Talb09* & $\begin{array}{l}\text { F: GGCCAGAAGCGTAAGTAGA } \\
\text { R: TGAGTGTATGTATTCGGCG }\end{array}$ & $(\mathrm{GCT})_{5}$ & 58 & 359 & 1 & - & - & - & JX437165 \\
\hline Talb12 & $\begin{array}{l}\text { F: AGGCTGGGCGTAGATTTC } \\
\text { R: TCGTATAACCTGTAGATAATGCC }\end{array}$ & $(\mathrm{TC})_{3} \mathrm{C}(\mathrm{TCG})_{6}$ & 58 & 211 & 1 & - & - & - & JX437166 \\
\hline Talb14 & $\begin{array}{l}\text { F: ACGAACACTGAGGTCCATAC } \\
\text { R: GCATTCAAATTAGGCATCTC }\end{array}$ & $(\mathrm{TG})_{5}$ & 48 & $245-249$ & 3 & 0.323 & 0.285 & 1 & $\mathrm{KC} 135872$ \\
\hline
\end{tabular}

* This locus was polymorphic for another T. albitarse population, presenting up to three alleles.

primers of which were end-labeled with fluorescence for genotyping using a MegaBace-1000 (GE) automated sequencer. Allele sizes were subsequently scored using the MegaBace Fragment Profiler program, version 1.2. The results of 37 genotyped females from different nests sampled in São Carlos (southeast Brazil; $22^{\circ} 01^{\prime} \mathrm{S}, 47^{\circ} 53^{\prime} \mathrm{W}$ ) revealed seven polymorphic and two monomorphic loci (Table 1). The genotyping of five additional populations revealed Talb09 to be polymorphic, with up to three alleles in the case of a nest from Araras (southeast Brazil, $22^{\circ} 21^{\prime} \mathrm{S}, 47^{\circ} 23^{\prime} \mathrm{W}$ ). The Genepop 4.0.10 (Raymond \& Rousset; 1995; Rousset, 2008) and Arlequin 3.11 (Excoffier et al., 2005) programs were used to estimate allelic diversity, heterozygosity, Hardy-Weinberg equilibrium (HWE) and linkage disequilibrium (LD) for the 37 females sampled in the São Carlos region. The number of alleles ranged from three to 11. Observed and expected heterozygosity on the population level ranged from 0.135 to 0.891 and 0.177 to 0.865 , respectively (Table 1). No null alleles were found, as amplification occurred for all 146 males analyzed from 22 nests. Furthermore, the sequential Bonferroni test (Rice, 1989) revealed no deviations from HWE or LD.

These markers were also found to be useful in cross amplifying DNA from other Trypoxylon species and the related sphecid genera Podium and Sceliphron using three to five specimens of each species (Table 2). All but one locus exhibited high rates of transferability, with positive amplification in most species (Table 2), but due to the low number of individuals analyzed, we have no informations about allelic variation on these other species. Previous reports highlight the importance of publication of monomorphic loci for the target species; they have shown that such loci may actually be polymorphic when tested in other closely related species (e.g. Vecchia et al., 2011).

With the polymorphic loci found, an assignment test was performed.using the GenAlex $6.4 \mathrm{v}$ program (Peakall \& Smouse 2006), with 291 individuals representing 22 nests (considered here as families) of $T$. albitarse. A total of $88 \%$ of the specimens were assigned to their original families, demonstrating the effectiveness of these loci in relatedness studies.

TABLE 2. Results of cross-species amplification using microsatellite primers designed for $T$. albitarse in nine related species of wasps.

\begin{tabular}{|c|c|c|c|c|c|c|c|c|c|}
\hline Locus & $\begin{array}{c}\text { Trypoxylon } \\
\text { lactitarse }\end{array}$ & $\begin{array}{l}\text { Trypoxylon } \\
\text { rogenhoferi }\end{array}$ & $\begin{array}{l}\text { Trypoxylon } \\
\text { aurifrons }\end{array}$ & $\begin{array}{l}\text { Trypoxylon } \\
\text { nitidum }\end{array}$ & $\begin{array}{l}\text { Trypoxylon } \\
\text { agamemnon }\end{array}$ & $\begin{array}{l}\text { Trypoxylon } \\
\text { opacum }\end{array}$ & $\begin{array}{l}\text { Trypoxylon } \\
\text { asuncicola }\end{array}$ & $\begin{array}{c}\text { Podium } \\
\text { denticulatum }\end{array}$ & $\begin{array}{c}\text { Sceliphron } \\
\text { caementarium }\end{array}$ \\
\hline Talb01 & - & - & - & - & - & - & - & - & + \\
\hline Talb02 & - & - & - & - & - & - & - & - & - \\
\hline Talb03 & + & + & + & + & + & + & + & + & + \\
\hline Talb05 & + & + & + & + & + & + & + & - & + \\
\hline Talb06 & + & + & + & + & + & + & - & - & - \\
\hline Talb07 & + & + & + & + & + & + & + & - & + \\
\hline Talb09 & + & + & + & + & + & + & + & + & + \\
\hline Talb12 & + & + & + & + & + & + & + & + & + \\
\hline Talb14 & - & + & + & + & + & - & - & - & - \\
\hline
\end{tabular}


The microsatellite loci described in the current study are the first for T. albitarse, and in fact, unique for any member of the genus Trypoxylon. Once Trypargilum males display the unusual guard behaviour, the developed microsatellite markers as here described may well prove useful in kinship studies, thereby providing insights into the mating system of these wasps. Crossspecies positive amplification results revealed that these markers can also be useful in genetic studies of closely-related wasp species. Lastly, we suspect that the polymorphic loci as described may also prove useful for future studies on the gene diversity, gene flow and genetic structure of natural populations of Trypoxylon species, more especially in terms of phylogeography and perhaps for some rarer species, conservation ecology-genetics

ACKNOWLEDGEMENTS. The authors are grateful for the financial support provided by Conselho Nacional de Desenvolvimento Científico e Tecnológico (CNPq-480706/2010) and H.D. Loxdale for his helpful comments on the manuscript.

\section{REFERENCES}

BROCKMANN H.J. 1992: Male behavior, courtship and nesting in Trypoxylon (Trypargilum) monteverdeae (Hymenoptera: Sphecidae). - J. Kans. Entomol. Soc. 65: 66-84.

Coville R.E. 1982: Wasps of the Genus Trypoxylon subgenus Trypargilum in the North America. University of California Press, Berkeley and Los Angeles, 147 pp.

Coville R.E. \& Coville P.L. 1980: Nesting biology and male behaviour of Trypoxylon (Trypargilum) tenoctitlan in Costa Rica (Hymenoptera: Sphecidae). - Ann. Entomol. Soc. Am. 73: $110-119$

Excoffier L., Laval G. \& SchNeider S. 2005: Arlequin ver. 3.0: An integrated software package for population genetics data analysis. - Evol. Bioinform. Online 1: 47-50.

Fernandes-Salomão T.M., Rocha R.B., CAmpos L.A.O. \& ARAÚJo E.E. 2005: The first internal transcribed spacer (ITS-1) from Melipona species (Hymenoptera: Apidae, Meliponini): characterization and phylogenetic analysis. Insectes Soc. 52: 11-18.
Freitas P.D., Martins D.S. \& Galleti P.M. JR 2008: CID: a rapid and efficient bioinformatic tool for the detection of SSRs from genomic libraries. - Mol. Ecol. Resour. 8: 107-108.

Hamilton M.B., Pincus E.L., Di Fiori A. \& Flesher R.C. 1999: Universal linker and ligation procedures for construction of genomic DNA libraries enriched for microsatellites. - Biotechniques 27: 500-507.

HugHEs C. 1998: Integrating molecular techniques with field methods in studies of social behavior: A revolution results. Ecology 79: 383-399.

Kaltenpoth M., Strohm E. \& Gadau J. 2004: Polymorphic microsatellite markers for a solitary digger wasp, the European beewolf (Philanthus triangulum; Hymenoptera, Sphecidae). - Mol. Ecol. Notes 4: 589-592.

Lucas E.R., Horsburgh G.J., Dawson D.A. \& Field J. 2009: Characterization of microsatellite loci isolated from the wasp, Microstigmus nigrophthalmus (Hymenoptera). - Mol. Ecol. Resour. 9: 1492-1497.

Peakall R. \& Smouse P.E. 2006: GENALEX 6: genetic analysis in Excel. Population genetic software for teaching and research. - Mol. Ecol. Notes 6: 288-295.

Queller D.C., Strassmann J.E. \& Hughes C.R. 1993: Microsatellites and kinship. - Trends Ecol. Evol. 8: 285-288.

RAYMOND M. \& RousSet F. 1995: GENEPOP (version 1.2): population genetics software for exact tests and ecumenicism. - J. Hered. 86: 248-249.

Rice W.R. 1989: Analyzing tables of statistical tests. - Evolution 43: 223-225.

ROUSSET F. 2008: Genepop'007: a complete reimplementation of the Genepop software for Windows and Linux. - Mol. Ecol. Resour. 8: 103-106.

Vecchia A.C.D., Biondo D., Sanches A., Keuroghlian A., Miyaki C.A., Galetti M. \& Galetti P.M. JR 2011: Isolation and characterization of microsatellite loci for white-lipped peccaries (Tayassu pecari) and cross-amplification in collared peccaries (Pecari tajacu). - Conserv. Genet. Resour. 3: 151-154.

Received December 4, 2012; revised and accepted December 20, 2012 